\title{
Hermeneutics Perspective: Number and Personal Grammatical Equivalence of Google Translate
}

\author{
Berlin Insan Pratiwi \\ STIE Putra Bangsa, Indonesia \\ Email: bipratiwi@gmail.com
}

Submitted: $12 / 12 / 2020$
Revised: 29/12/2020

Abstract. Due to translation process by Google Translate (GT) is recently common, analyzing its translation equivalence is required. Conducted as descriptive qualitative research, this content analysis study provides descriptions of number and personal equivalence aspects toward sentence meaning in hermeneutics view. There were 90 English sentences analyzed as research sample resulting 7 types of meaning equivalence phenomenon: 1) target text (TT) has number equivalent meaning and the sentence is hermeneutically accepted, 2) TT has no number equivalent meaning yet the sentence is hermeneutically accepted, 3) TT has no number equivalent meaning and the sentence is not hermeneutically accepted, 4) TT has personal equivalent meaning and the sentence is hermeneutically accepted, 5) TT has no personal equivalent meaning yet the sentence is hermeneutically accepted, 6) TT has no personal equivalent meaning and the sentence is not hermeneutically accepted, and 7) both personal meaning equivalence and sentence hermeneutics point of view cannot be identified due to clusivity of Indonesian. It is concluded that GT is able to provide $53 \%$ meaning accuracy in terms of number aspect and $86.6 \%$ of number aspect sentences are hermeneutically accepted. GT provides $53 \%$ meaning accuracy in personal aspect and $73.3 \%$ of personal aspect sentences are hermeneutically accepted. Figures show higher hermeneutical acceptance than the meaning equivalent indicate that GT in Indonesian is considered to be understandable for basic need of clause and sentence level for common information in terms of number and personal equivalence, but for detailed information especially those of number, masculine/feminine, and clusivity phenomenon in Indonesian more enhancement for accuracy is needed.

Keywords: meaning equivalence, hermeneutics, clusivity

\section{https://ojs.unm.ac.id/eralingua}

This work is licensed under a Creative Commons Attribution-NonCommercial 4.0 International License 


\section{INTRODUCTION}

Bridging is the essence of every translation and efforts come with it. Translation bridges languages and reduces barriers among languages which is salient in most human contact. Globalized world and multilingual society people live in puts translation even more prominent. Translation plays as an important aspect in most fields. It is obvious that although some languages function as lingua franca, some people prefers to interact and communicate in their own native language (Saha, 2020). Thus, the need to connect the different languages becomes a necessity.

Translation is ideally brought by the core principle of meaning equivalence as it is preserved in the source text. Translator, by any means, should be able to serve the same effect as the source text (Newmark, 1986); (Nida \& Taber, 2003). Nord (2018) states an ideal translation as (an) integral communicative performance in which the aim in the TL (target language) is equivalence as regards the conceptual content, linguistic form, and communicative function of a SL (source-language) text". The importance of the functional aspects in translation shows that functional ideas in translation are the key so that the act of translation presents a translation text that has accuracy and can be read, understood, and has the same effect as that in the source text.

The concept of equivalence is a central thing that is often discussed in translation studies and research (Panou, 2013). Critical evaluation has been carried out in an effort to describe the various equivalence concepts conveyed by translation experts ranging from Vinay and Darbelnet, Jakobson, Nida and Taber, Catford, House, Koller, Newmark, Baker, and Pym. Framework of this research follows Baker in particular. Baker (2018) states language grammar as a set of rules that determines the way for each linguistic unit to be combined in a language. Grammar also includes information about things that must be done regularly and explicitly in language speech. The grammar of a person comes with its relation to the participatory function in speech. In simple terms, this personal form appears in the form of a pronoun (Baker, 2018).

The grammatical aspect of number refers to a concept known to all humans which functions to indicate the count-ability of an object (Baker, 2018). Numbers are described in the lexical structure found in all languages, but not all languages have a grammatical category that includes numbers. English is a language that recognizes the concept of numbers at the lexical and grammatical levels, which is plural and singular; while some other languages (for example Japanese, Chinese, Indonesian, and Vietnamese) indicate numbers lexically, not grammatically. In these languages the plurality of an object does not appear in the form of a noun which changes form due to pluralism.

There are two choices for the translator to choose in doing translation process, i.e. pushing the reader to the writer or pushing the writer to the reader (Dai, 2019). The former option is commonly known as foreignizing/alienation and the latter is domestication as proposed by Venuti. Domestication is the process of conforming foreign text to the cultural values of the target language, while 
foreignizing/alienation is the process of preserving cultural values of the source language into the target language (Yang, 2017); (Gang \& Mahadi, 2020).

Hermeneutical approach in translation being fundamental in comprehending translation process and the result. The hermeneutics view in translation as a modern linguistic philosophy is often referred to as a theory of comprehension Stolze (2012) related to the question of 'whether we can understand at all' so that it is way more holistic, not merely 'how we understand' or 'what we understand'. Stolze (2012) states that hermeneutics philosophy departure point is the individual as a historical and social person who wants to orient him/herself in the surrounding world, to understand others, and act in the society. Social contribution is an aspect that appears in the act of translation, namely the process of bridging understanding of something in one language to another.

Tou (2008) defines that hermeneutics views the source text itself as a form of translation that translates the meaning of the author/speaker's mind. Further he states the following translation activities by the translator of the text are declared as a translation of the translation. Thus the hermeneutics concept of translation places meaning as the core of translation activities. Translation in hermeneutics view is translation that is inclined or oriented towards the target language and all its language, culture, and customary tools. Bukowski in Piecychna (2013) states that a translator's hermeneutics competence includes responsibility for the interpretations presented, knowledge of cultural and historical contexts, knowledge related to literature and target language literacy, general and specific understanding of the text, and the ability to communicate through the text. Thus the translator is seen as a co-author produces versions in other languages and acts domesticating foreignness. In addition, the basic hermeneutics view has a holistic approach in addressing the text. This differs from the atomic structuralist approach which views words as translation units (Stefanink \& Bălăcescu, 2017).

Hermeneutics contains prejudices in understanding and interpreting the world. Hermeneutics views emerging understanding as a compilation of experiences that have been experienced. Gadamer in Kuswarini (2016) stated that hermeneutics is not an approach used to determine truth, but as a praxis that reads text while trying to understand the various circumstances that can make truth possible. The hermeneutics approach in translation is an approach that has the best closeness to the ideal form of translation practice, namely translation that focuses on translating meanings instead of translating words (Stefanink \& Bălăcescu, 2017). It is further stated that the characteristics of hermeneutics translation are the combination of subjectivity, creativity, metaphoric legitimacy, and the corporeality of understanding in its theoretical reflection.

Subjectivity in a hermeneutics view is inevitable. This is because to be able to understand something, preceding information is needed about that certain thing. It is undeniable that this fore-understanding has a great opportunity to change later in the translation process. The progress of the translation has resulted in the complete meaning of the meaning formed in the translator's mind which originated from a fore-understanding which is later called by Stefanink and Bălăcescu (2017) to produce harmony regarding the meaning of the text for the translator. This fore- 
understanding then triggers the subjectivity of translation. For hermeneutics translators, the translation process is considered complete if the target language text has generated a mental representation of the meaning contained in the source text. This correspondence must be obtained by the translator in hermeneutics view.

Hermeneutics of translation views the translator's creativity as something common in the translation process. In addition, creativity is also referred to as a form of problem-solving activity in an effort to overcome existing obstacles related to cultural aspects. In hermeneutics view, the original tone contained in the source text must be maintained. The removal of the original tone is stated as a form of betrayal of the original text. Often, maintaining the original tone requires the creativity of the translator. Stefanink \& Bălăcescu (2017) state that the hermeneutics approach encourages translators to use their creativity to solve translation problems through lateral thinking or divergent thinking. In connection with encouraging the emergence of creativity, the hermeneutics approach also describes the epistemological value of metaphors that must be considered. The hermeneutics view legitimizes the use of metaphors in translation. Astari et al., (2019) states when a metaphor doesn't meet the commonness in target reader, translator may provide further description to convey the equivalent message as it is in source text.

Translation is a unique form of human intellectuality realization. The uniqueness contained in a series of translation activities is due to the process that occurs in it including consideration of cultural aspects, target audiences, target language prevalence, and others. These uniqueness usually requires human involvement to be able to adjust the various aspects found in the process. It becomes the basis for categorizing translation as an art, which in Newmark (1986) statement is referred to as craft. The absence of human involvement in translation process is assumed to be one of the factors causing the inaccuracy of the translation results, especially in the aspect of target text grammatical equivalence.

The current digital advancement is a common form of the 4.0 era. These advances have also influenced views on translation, especially the translation process, which currently can not only be carried out by humans but can also be completed by artificial intelligent forms, especially machine translation (MT). Google Translate (GT) is one of the most commonly used machine-based translation as it is free to access.

Google Translate is a machine translator developed by Google Inc. (Li et al., 2014). GT is operated with a translation statistical engine (Brown et al. in Li et al., 2014) which uses linguistic modeling, statistical decision theory, and matching probabilities (Ney in Li et al., 2014) which functions to determine the most frequent form of translation used. Some of the most popular systems included in GT include the phrase-based model with small text chunks and reordering, hierarchical phrasebased models, and hierarchical and syntactic models.

Preceding researchers have found that GT as a machine-based translation deals with some shortcomings. Li et al., (2014) states that the results of the GT translation have a close relationship with the results of human translations in terms of semantics and pragmatics, but in terms of syntax and grammar, it needs improvement. Other research conducted by Angi (2019), however, shows GT serves 
a good result in term of grammatical equivalence. These two contrastive overviews lead the researcher to conduct further research to find out grammatical equivalence of GT in Indonesian. It is also a form of attempt to provide further finding as the two previous findings came to different description of GT translation equivalence specifically grammatical equivalence of person and number. This research carries a novelty in term of relating number and personal grammatical equivalence and hermeneutics approach in translation.

\section{RESEARCH METHOD}

This research uses descriptive research method with the aim of producing a natural data description. The narrative descriptions produced by this method are expected to be factual and accurate as a reflection of the overall data. The design used in this study is qualitative. The type of research used is content analysis so that research can be carried out objectively and systematically. Krippendorff (2004) states content analysis as a research technique for making replicable and valid inferences from data to their context. This type of content analysis research was chosen because the researcher wanted to describe the dynamic equivalent form and the prevalence of the English-Indonesian translation text produced by Google Translate from hermeneutics point of view.

The object in this study is linguistic semiotics, namely the text of the translation by MT GT. Ninety units of analysis were taken from Business English tenth edition written by Guffey and Seefer published in 2011 by Cengage Learning. The units of analysis used in this research are clauses and sentences. The clauses and sentences were taken by purposive sampling according to the data requirements needed. Data collection techniques used in this study were observation and read-note. Researchers collected and observed data contained in the source. The data then processed by inputting to GT and the results are read online. The processing results by GT were then recorded.

The analysis technique in this study was carried out using the equivalent method (metode padan) in which the determining tool was another language. This method was chosen based on the theoretical basis presented by Sudaryanto (2015) which states that this sub-type matching method allows researchers to adjust, harmonize, match, equate, or match a lingual unit with the identity or authenticity of its determining elements. The components of this research include data collection, data reduction, data presentation, and drawing conclusions.

\section{RESULT AND DISCUSSION}

The aspect of grammatical equivalence based on Baker's (2011) theory in this research is associated with the hermeneutics perspective presented by Stolze (2012) and Stefanink \& Bălăcescu (2017). Anari \& Safdari (2017) state that translation is a dynamic action that must be carried out on the basis of understanding the source text. This causes the hermeneutics approach to become fundamental in the implementation of translation. Following are the results of the analysis of the results of the GT translation on the grammatical equivalence aspect of the number and the person in relation to the hermeneutics perspective of translation. 
There are 3 types of translation phenomenon in number aspect of grammatical equivalent: 1) the translation result has number aspect equivalent meaning and the sentence meaning is accepted in hermeneutics view, 2) the translation result has no number aspect equivalent meaning yet the sentence meaning is acceptable in hermeneutics view, and 3) the translation result has no number aspect equivalent meaning and the sentence meaning is not acceptable in hermeneutics view.

Table 1. Number Equivalence and Sentence-Hermeneutically Acceptance

\begin{tabular}{ccccc}
\hline \multirow{2}{*}{ No } & \multicolumn{2}{c}{ Types of Phenomenon } & & \\
\cline { 2 - 4 } & $\begin{array}{c}\text { Number } \\
\text { Equivalence }\end{array}$ & $\begin{array}{c}\text { Hermeneutics } \\
\text { Acceptance }\end{array}$ & Amount & $\%$ \\
\hline $\mathbf{1}$ & $\checkmark$ & $\checkmark$ & 24 & 53.33 \\
\hline $\mathbf{2}$ & $\mathbf{X}$ & $\checkmark$ & 15 & 33.33 \\
\hline $\mathbf{3}$ & $\mathbf{X}$ & $\mathbf{X}$ & 6 & 13.33 \\
\hline
\end{tabular}

\section{KGJ 3}

ST: $\quad$ Filipinos take pride in their personal appearance, they believe a person's clothing indicates social position.

TT: Warga Filipina bangga dengan penampilan pribadinya, mereka percaya pakaian seseorang menunjukkan posisi sosial.

Saidi (2008) states that the translated text is not limited to written autonomous facts, but has a scope of context, in which there are several aspects to support the integrity of meaning. The GT translation shows that there is a grammatical equivalent in the aspect of numbers. Context adjustments have been made in the realization of the translation by GT. The grammatical equivalent of the number aspect for 'Filipinos' is 'orang-orang Filipina' or 'warga Filipina'. Online KBBI states that the word 'warga' includes both the singular and the plural number (person, community, population, population, etc.). Hermeneutics point of view judges the above translation as a good form of translation because there has been an adjustment in the prevalence of the target language in the target text.

GT's choice to bring out 'warga Filipina' instead of 'orang-orang Filipina' is seen as an adaptation connected to hermeneutics perspective. This is because in the context of prevalence in Indonesian, the term 'warga Filipina' is commonly accepted as a plural form. If we assume that GT is a human translator, this could be a form of creativity (which is showing the usual form in the target language domesticating foreigness) which is implemented in the target text. Thus the translation is an ideal form of translation seen from a hermeneutics perspective because the translation focuses on translating meanings rather than translating words (Stefanink \& Bălăcescu, 2017). 
KGJ 22

ST: Russian children usually open gifts in private, however, Russian adults usually open gifts in front of their gift givers.

TT: Anak-anak Rusia biasanya membuka hadiah secara pribadi, namun, orang dewasa Rusia biasanya membuka hadiah di awal pemberian hadiah mereka.

Indonesian is not a language uses changes in the form of a noun in the case of making plural, that is, the form of pluralism occurs in a lexical, not grammatical aspect. It is different from English, which uses a change in the form of a noun when it is plural, which uses the concept of changing the lexical and grammatical aspects. In the data, the phrase 'Russian children' is translated into 'anak-anak Rusia'. This form is the grammatical equivalent of the amount presented by GT. When viewed from the views of Newmark (1986) and Nida \& Taber (2003) which state that the similarity of meaning must appear in the translation result and be examined from hermeneutics point of view, the retention of meaning that occurs in this translation is a form of translation accuracy by GT. Thus both grammatical equivalence and hermeneutics views on these data are linear.

KGJ 35

ST: $\quad$ Interns in our company receive instruction and encouragement.

TT: $\quad$ Magang di perusahaan kami menerima instruksi dan dorongan.

The above data indicates an explicit mismatch of numerical aspects of grammar, but from hermeneutics point of view it is a good form of translation. The absence of the plural form in the target language has caused the grammatical equivalent not to be achieved. However, for native speakers of Indonesian this is acceptable because this form is commonly used. This is a form of domesticating foreignness, which is presenting a form that is common in the target language. This finding is in line with Pratiwi \& Kartikarini (2018) state their findings were related to the attachment of ST and TT, namely TT can emerge as a new text in various aspects, in this case its novelty appears in a form that conforms to the general usage of Indonesian speakers. Related to Stolze (2012) states the hermeneutics concept of 'whether we can understand at all', this translation has been complete in the process if it is referred to from the perspective of Indonesian readers. Traced on Badan Bahasa Indonesian language is stated as a language that does not recognize the plural and singular forms like in English (Kebudayaan, n.d.). It means that nouns in Indonesian are neutral and their plurality will appear if they are made in the form of phrases and higher levels, namely by means of repetition, adding numerals, adding quantifiers, and so on. Thus the meaning of the translation is correct seen from its prevalence in Indonesian and is classified as an ideal translation in hermeneutics view.

KGJ 41

ST: $\quad$ Athletic shoe makers convinced us to buy $\$ 150$ tennis shoes.

TT: $\quad$ Pembuat sepatu atletik meyakinkan kami untuk membeli sepatu tenis \$150.

This data shows the unattainable grammatical equivalence in the number and classified as bad translation text in hermeneutics perspective. The plural of the original text 'makers' does not appear in the translation 'pembuat'. Although in Indonesian the noun is neutral, contextually this sentence requires an explicit explanation of the subject involved in the activity as a form of describing its holistic 
effect. The ideal translation should be able to give the target text the same effect as the source text reader. Judging from its function in communicative translation, there is an effort to produce an effect for the target language readers that is as close as possible to the effect received by the source language on the reader (Newmark, 1986). The absence of this same effect is then the reason this sentence is justified as a bad translation from hermeneutics perspective. Domesticating foreignness attempt that occurred in translating this sentence resulted in a loss of meaning which was a counter form of hermeneutics goals as a betrayal of the translation of the original tone (Stefanink \& Bălăcescu, 2017).

There are 4 types of translation phenomenon in the aspect of personal equivalence: 1) the translation result has personal aspect equivalent meaning and the sentence meaning is accepted in hermeneutics view, 2) the translation result has no personal aspect equivalent meaning yet the sentence meaning is accepted in hermeneutics view, 3) the translation result has no personal aspect equivalent meaning and the sentence meaning is not acceptable in hermeneutics view, and 4) both personal meaning equivalence and its hermeneutics point of view cannot be identified.

Table 2. Personal Equivalence and Sentence-Hermeneutically Acceptance

\begin{tabular}{ccccc}
\hline \multirow{2}{*}{ No } & \multicolumn{2}{c}{ Types of Phenomenon } & & \\
\cline { 2 - 4 } & $\begin{array}{c}\text { Personal } \\
\text { Equivalence }\end{array}$ & $\begin{array}{c}\text { Hermeneutics } \\
\text { Acceptance }\end{array}$ & Amount & $\%$ \\
\hline $\mathbf{1}$ & $\checkmark$ & $\checkmark$ & 24 & 53.33 \\
\hline $\mathbf{2}$ & $\mathbf{x}$ & $\checkmark$ & 9 & 20.00 \\
\hline 3 & $\mathbf{x}$ & $\mathbf{x}$ & 6 & 13.33 \\
\hline 4 & $?$ & $?$ & & \\
\hline
\end{tabular}

KGP 9

ST: $\quad$ Are you sure it was her who called me yesterday?

$\mathrm{TT}$ : Apakah Anda yakin itu dia yang memanggil saya kemarin?

The above data has grammatical equivalence of personal aspect and its sentence meaning is accepted by hermeneutics perspective. In hermeneutics point of view, understanding and interpretation of meaning cannot be separated from prejudice (Kuswarini, 2016). This kind of prejudice appears in choosing the form of 'Anda'. Although in Indonesian the word 'you' can be interpreted as 'kamu, Anda, dan kalian', in this sentence the form 'Anda' is considered more appropriate in the context of situations that generally occur, namely the context of situations confronting the truth of things to others. Generally this kind of confrontation happens to one person so that it is not the form of 'kalian' is chosen. However, it is very likely that GT does not translate into 'kalian' which should have a plural connotation in the context of a particular situation. Although this form of 'you Anda' is appropriate from the personal aspect and hermeneutics point of view, in higher level of sentence case the hermeneutics point of view holistically judges this sentence unit has shortcoming. This hermeneutically-sentence-level-unacceptance is caused by the form of speech considered to be unusual in both target language and culture. 
KGP 16

ST: $\quad$ She analyzed the research implications.

TT: Dia menganalisis implikasi penelitian.

This data illustrates the existence of a grammatical mismatch of the personal aspect that occurs in the word 'she' translated into 'dia'. The fundamental difference of linguistic system between English and Indonesian, namely the existence of masculine and feminine concepts in English personal pronouns and possessive pronouns, causes this mismatch in all forms of English personal that contain masculine and feminine elements. Creativity from hermeneutics point of view can be used to solve problems in the translation process (Stefanink \& Bălăcescu, 2017), but this creativity item may not be possible for GT to run so that it does not provide information about the masculine/feminine subject or object involved in translation presented. Although the grammatical agreement on personal aspect is not achieved, yet its sentence meaning is accepted by hermeneutics perspective. Hermeneutics point of view regarding the domesticating foreignness process in translation judges the translation result as a good form because it is compatible with the usual form in Indonesian which does not use masculine/feminine concepts.

KGP 31

ST: $\quad$ She enjoys reading as much as he.

TT: $\quad$ Dia menikmati membaca sebanyak dia.

This data does not reflect the grammatical equivalence of the personal aspect. In addition, the justification made based on the hermeneutics point of view narrows the statement regarding the data as a non-ideal translation. Stolze (2012) states that hermeneutics plays a role in acting in the society. In this case the form of action that must be carried out by a good translation is in interpreting the meaning of diction in understandable linguistic concepts. In this data, the meaning of the source text related to the persona aspect is not fully realized because of the absence of masculine/feminine indications. The meaning of the sentence unit becomes ambiguous and is not normally formed in Indonesian, namely by the appearance of the two forms of the word 'dia'. In addition, if it is related to Nord (2018) states that the ideal translation should fulfill its functional aspects in translation, then this form of translation cannot be classified as a form that fulfills the functional aspects of language. It means that the functional idea in translation as the key to the statement is not achieved because the act of translation does not have elements that can be read and understood, and does not have the effect that is contained in the source text. In short, this form of translation is not accepted by hermeneutics perspective.

KGP 40

ST: We need more politicians like him.

TT: $\quad$ Kami membutuhkan lebih banyak politisi seperti dia.

Indonesian language recognizes the forms of 'kami' (exclusive) and 'kita' (inclusive), the use of which is distinguished by the involvement of the interlocutor in the activity being conveyed (Lanin, 2015). It is different from English, which does not explicitly recognize the form of clusivity such as Indonesian, which only recognizes the form of 'we', so it needs further consideration when translating the 
word 'we' into Indonesian. This data shows confusion in the choice of words in the personal aspect, namely the use of the word 'kami' which may be meant by 'kita' by source text author. The justification of using the word "kami" or "kita" in this sentence requires additional information which is unfortunately not available because the data found is a loose sentence, not a paragraph. If there is a continuation of a sentence describing the situation, this kind of data is an example of data that requires further consideration from a non-machine translator. The process of "acting on society" as stated by Stolze (2012) will occur as a whole with the ability to adjust the context which is part of human creativity. In addition, viewed from translator competence point of view of based on Bukowski in Piecychna (2013), MT GT's hermeneutics competence in the data is not fulfilled because the elements of interpretation produced are still vague for target readers and do not consider the Indonesian language cultural context which recognizes clusivity. Thus the discussion of this data cannot be continued in determining the grammatical equivalence of its personal aspect. Further, captured from hermeneutics perspective the sentence cannot be justified in its idealism of meaning transfer.

Grammatical equivalence that is manifested in the translation results is ideally linear with the transfer of meaning which is closely related in hermeneutics studies, however, in the data studied, it was found that the grammatical equivalence that did not appear in the translation results could also be seen as something good from hermeneutics perspective. This is due to the possibility of the target language approach being the consideration in translating certain clauses/sentences by GT. It is found in the pronoun form which is contained in the personal aspect. It is also found in term of numeral aspect. If the prevalence of the target language requires a new form that appears in the translation, then the hermeneutics point of view sees this form as the ideal product of translation. In this study, it was found that there is a phenomenon of clusivity in Indonesian but not in English affecting translation equivalence and meaning transfer quality served by Google Translate.

\section{CONCLUSION}

GT is considered to be understandable for basic need of number and personal meaning equivalence. Its current translation support ability appropriates for the unit level of clause and sentence for common and general information in terms of number and person meaning equivalence. The following findings meets the research objectives as it provides description of number and personal meaning equivalence as served by GT. Finding shows $53 \%$ accuracy of number aspect and $86.6 \%$ hermeneutically-accepted sentences of number aspect in Indonesian as the target text; while in term of person meaning accuracy, GT provides 53\% - the same figure as the number aspect - and $73.3 \%$ of personal aspect sentences are hermeneutically accepted. Nevertheless, for the purposes of deeper and detailed information of number, masculine/feminine, and especially those of clusivity in Indonesian more enhancement for accuracy is an improvement mandatorily needed. Further studies with more complex unit of analysis (paragraph) can be carried out to obtain wider overview of the decision making by GT regarding the 
number aspect, masculine/feminine aspect, and especially clusivity occurs in EnglishIndonesian vice versa translation form.

\section{REFERENCES}

Anari, S. M., \& Safdari, F. (2017). Translation as interpretation: a hermeneutical view toward translation. The Scientific Research Journal of Translation Studies, 15(58).

Angi, B. R. R. (2019). Kualitas terjemahan itranslate dan Google Translate dari bahasa Inggris ke dalam bahasa Indonesia. Deskripsi Bahasa, 2(November 2016),6-11.https://doi.org/10.22146/db.v2i1.337

Astari, G. P., Hasyim, M., \& Kuswarini, P. (2019). Penerjemahan metafora novel "Lelaki Harimau " ke dalam “L’Homme Tigre." Jurnal Ilmu Budaya, 7(1), 8393.

Baker, M. (2018). In other words: A coursebook on translation. London: Routledge.

Dai, L. (2019). Empiricism and hermeneutics in descriptive translation studies. 3rd International Conference on Economics and Management, Education, Humanities and Social Sciences (EMEHSS 2019), 325, 233-236. https://doi.org/10.2991/emehss-19.2019.47

Gang, A., \& Mahadi, T. (2020). Conceptualising the issues of translation culture in China : the roles of domestication and foreignization. International Journal of Innovation, Creativity and Change, 13(10), 876-886.

Kebudayaan, K. P. dan. (n.d.). Para hadirin dan para ulama. http://badanbahasa.kemdikbud.go.id/lamanbahasa/petunjuk_praktis/725

Krippendorff, K. (2004). Content analysis: an introduction to its methodology. Berverly Hills: Sage Publications.

Kuswarini, P. (2016). Penerjemahan, Intertekstualitas, Hermeneutika Dan Estetika Resepsi. Jurnal Ilmu Budaya, 4(1), 39-47.

Lanin, I. (2015). Kita dan kami. https://beritagar.id/artikel/tabik/kita-dan-kami

Li, H., Graesser, A. C., \& Cai, Z. (2014). Comparison of Google translation with human translation. Twenty-Seventh International Flairs Conference.

Newmark, P. (1986). Approaches to translation. Oxford: Pergamon Press Ltd.

Nida, E. A., \& Taber, C. R. (2003). The theory and practice of translation. Leiden: EJ Brill.

Nord, C. (2018). Translating as a purposeful activity: functionalist approaches explained. London: Routledge.

Panou, D. (2013). Equivalence in translation theories: a critical evaluation. Theory and Practice in Language Studies, 3(1), 1-6. https://doi.org/10.4304/tpls.3.1.1-6

Piecychna, B. (2013). Legal translation competence in the light of translational hermeneutics. Studies in Logic, Grammar and Rhetoric, 34(47), 141-159. https://doi.org/10.2478/slgr-2013-0027

Pratiwi, B. I., \& Kartikarini, T. (2018). Experiential meaning breadth variation of British Broadcasting Corporation (BBC) Indonesia online news. LingTera, 5(1), 89-98. https://doi.org/10.21831/lt.v5i1.7695

Saha, A. (2020). Importance of Translation and Translation as a Means of Language Development. International Journal of English Learning \& Teaching Skills, 2(3), 1361-1374. https://doi.org/https://doi.org/10.15864/ijelts.2307 
Saidi, A. I. (2008). Hermeneutika, sebuah cara untuk memahami teks. Jurnal Sosioteknologi, 7(13), 376-382.

Stefanink, B., \& Bălăcescu, I. (2017). The hermeneutical approach in translation tudies. Cadernos de Tradução, 37(3), 21. https://doi.org/10.5007/21757968.2017v37n3p21

Stolze, R. (2012). The hermeneutical approach to translation. Vertimo Studijos, 5, 3042. https://doi.org/10.15388/VertStud.2012.5.10557

Sudaryanto. (2015). Metode dan aneka teknik analisis bahasa. Yogyakarta: Sanata Dharma Univeristy Press.

Tou, A. B. (2008). The translatics of translation. Journal of Modern Languages, 18(1), $15-39$.

Yang, Y. (2017). Analysis of foreignization and domestication in translation strategy from cross-cultural perspective. 4th International Conference on Literature, Linguistics and Arts (ICLLA 2017) Analysis, 76-81. https://doi.org/10.25236/iclla.2017.17 